\title{
Tüketicilerin Pandemi Sürecindeki Satın Alma Davranışlarının Cinsiyetlere Göre İncelenmesi
}

\author{
EsRa KOÇ (i) ${ }^{1}$ FATma Fehime AYDIN (iD) ${ }^{2}$
}

Başvuru: 11.05.2021; Düzenlenme: 15.06.2021; Kabul: 26.06.2021

\begin{abstract}
2019 yılınn sonlarında ortaya çıkan COVID-19 pandemisi tüm dünyayı önemli derecede etkilemiştir. COVID-19 pandemisini önlemek amacıyla hükümetlerce kullanılan politikalar da tüketicilerin davranışlarını etkilemiştir. Olağandış bir durum olarak ortaya çıkan pandeminin tüketicilerin satın alma davranışlarını nasıl etkileyeceğinin tahmin edilmesi kolay değildir. Çalısmada COVID-19'un tüketicilerin satın alma davranısı üzerindeki etkisinin cinsiyet faktörüne bağlı olarak araştırılması amaçlanmıştır. Bu amaca yönelik olarak çalısmada anket yöntemi uygulanmıştır. Çalısmanın örneklemi 397 kişiden oluşmaktadır. Türkiye bazında yapılan anket çalısmasında ttesti ve varyans analizi kullanılmıştır. Araştırma sonucunda elde edilen bulgulara göre COVID-19 döneminde tüketicilerin davranışlarının önemli derecede değiştiği ve bu değişikliklerin özellikle temel ihtiyaçlarından olan fizyolojik ve güvenlik ihtiyaçlarını karşılamaya yönelik değiş̧iklikler olduğu tespit edilmiştir. Kadın ve erkeklerin davranışlarında da anlamlı düzeyde bir farklılık gözlemlenmiştir. Kadınların panik durumunda ihtiyaç fazlası alı̧̧veriş yaptığı, erkeklerin ise online tüketime daha fazla ilgi gösterdiği gözlemlenmiştir. Kadın ve erkeklerin benzer davranı̧̧lar sergilediği durumlar da olmuştur. Örneğin salgın döneminde hastalıkla mücadelede sağlıklı beslenme ve hijyen ürünlerine olan talebin hem kadınlar hem de erkekler için önemli derecede arttiğ tespit edilmiştir.
\end{abstract}

JEL kodları: D12, D91, I18

Anahtar kelimeler: Covid-19 Pandemisi, Tüketici Davranışı, Cinsiyet Etkisi

\section{Giriş}

Çin'in Vuhan Eyaleti'nde 2019 yılı Aralık ayının sonlarında ilk olarak görülen ve son derece bulaşıcı ve ölümcül olan Covid-19 pandemisi kısa sürede tüm dünyayı etkisi al-

1 Anadolu Üniversitesi, Eskişehir, Türkiye, e-posta: e_k@anadolu.edu.tr

2 Van Yüzüncü Yıl Üniversitesi, Van, Türkiye, eposta: fatmafehimeaydin@yyu.edu.tr tına almıştır. Ülkeler salgından korunabilmek amacıyla farklı kısıtlama politikalarını uygulamaya koymuşlardır. Ancak bu uygulamalar aynı zamanda birçok köklü değişime yol açmıştır. Bu değişimler, tüketicilerin alışkanlıklarını değiştirmeleri ve farklı alışkanlıklar edinmelerini gerektirmiştir. Günlük yaşantımizda ve pazarlama dünyasında, tüketim ve tüketici davranışları önemli bir yere sahiptir. Dolayısıyla daha önceden Covid-19 pandemi 
dönemine benzer bir durum yaşanmadığından, pandeminin tüketici davranıslarında bir değişime neden olup olmadığının, değişim olduysa hangi değişimlerin olduğunun belirlenmesi ve cinsiyet faktörüne göre de tüketici davranışlarında bir farklılık olup olmadığ ${ }_{1-}$ nın bilinmesi, literatüre sağlayacağı katkıdan ötürü önem arz etmektedir.

Literatürde yapılan çalışmalar neticesinde, farklı cinsiyetteki tüketicilerin, satın alma davranışlarının, zevklerine, duygularına, satın aldıkları ürünün rengine ve şekline göre değişebileceği bilinmektedir. Tüketici satın alma davranışını şekillendiren birçok faktör vardır. Bunlardan biri de demografik özeliklerden biri olan cinsiyet faktörüdür. Dolayısıyla bu çalışmada Covid-19 süreciyle beraber değişen tüketici satın alma davranışındaki değişimlerin cinsiyet faktörüne göre nasıl şekillendiği incelenmiştir. Çalışmada ilk olarak literatür taraması yapılmış ve devaminda Covid-19 döneminde cinsiyetin satın alma davranışı üzerindeki etkisinden bahsedilmiş ve son olarak da çalışmada elde edilen bulgulardan bahsedilmiştir. Çalışmada tercih edilen anket yöntemi verilerine göre, Covid-19 döneminde tüketicilerin satın alma davranışları cinsiyet faktörüne göre anlamlı farklılıklar göstermiştir.

\section{Literatür}

Covid-19 pandemisi yakın zamanda gündeme düşen bir konu olduğu için konu ile ilgili literatürde çok fazla çalışma yer almamaktadır. Sınırlı sayıda olan bu çalışmalardan biri Vijai ve Nivetha tarafindan 2020 yılında Hindistan'ın dördüncü büyük metropol şehri olan Chennai şehrinde yaşayan 256 katılımcıya anket uygulanarak yapılmıştır. Çalışmadan elde edilen sonuçlara göre tüketicilerin satın alma davranışının temelden değiştiği ve tüketicilerin sağlık ve hijyen ürünlerine daha fazla para harcadığ tercihinin etkilendiği görülmüştür (Vijai ve Nivetha, 2020).

Ben Hassen vd. tarafından 2020 yllında Katar hükümeti üzerine yapılan ve tüketici bilinci, gıda tüketimiyle ilgili tutumlar ve davranışlar üzerindeki anlık etkilerin araştırıldığı bir çalışmada, tüketicilerin yemek yeme, alışveriş yapma ve yiyecekle etkileşimde bulunma şekillerinde net değişiklikler olduğu ortaya koyulmuştur. Çalışmadan elde edilen sonuçlara göre Katar'da daha sağlıklı diyetlere doğru bir geçiş olduğu; gıda güvenliği endişelerinden dolayı yerli ürünlerin tüketiminde bir artış olduğu; yiyecek edinme yönteminde bir değişiklik olduğu (çevrimiçi market alışverişinde bir artışla birlikte); yemek pişirme yeteneklerinde bir artış olduğu ve Katar'da panik satın alma ve yiyecek stoklama olmadı̆̆ gözlemlenmiştir (Hassen vd., 2020).

Brizi ve Baraglia tarafindan 2021 yllında Amerika ve Hindistan'da yapılan uluslararası bir anket çalışmasına göre COVID-19 salgını, bireyleri yiyecek stoklamaya teşvik etmiştir. Bununla birlikte, bireylerin stoklanan gidanın önemli bir kısmını tüketmediği ve artan miktarda ürün israfının söz konusu olduğu görülmüştür. Araştırmadan elde edilen bulgulara göre sokağa çıkma kısıtlamasına riayet eden bireylerin ihtiyacından fazla ürün stokladığı ve bunun da gıda israfına yol açtığı tespit edilmiştir. Tüketicilerin cinsiyetlerinin ve hangi ülkede ikamet ettiklerinin bu konuda etkili olduğu anlaşılmıştır. Amerika ve Hindistan üzerine yapılan bu çalışmada Hindistan vatandaşlarında ve özellikle kadınlarda bu durumun daha belirgin olduğu tespit edilmiştir (Brizi ve Biraglia, 2021).

Clevence vd. tarafindan 2020 yilında Amerika Birleşik Devletler'inde yaşayan 344 kişi üzerine yapılan bir anket çalışmasında, COVID-19'un yayılmasının ilk aşamalarında kimlerin güvenlik ve sağllk bakım ürünlerini önlem amaçlı satın aldığını ve bu eylemi neyin uyardığını incelemişlerdir. Çalışmanın sonuçları, yaş, cinsiyet, ırk veya gelirdeki farklılıkların değil, bir COVID-19 risk faktörüne sahip olmanın veya bu risk faktörüne sahip olma konusundaki belirsizliğin ve endişenin önlem amaçlı olarak sağlık ve güvenlik ürünlerinin satın alımını artırdığını göstermiştir. Covid-19 başlangıcında çok endişeli olmayan erkeklerin ürün satın alımı ar- 
tarken, daha çok endişe duyan kadınların ise ürün satın alımının çok artmadı̆̆̆ görülmüştür (Clemens vd., 2020).

Wang vd. tarafından 2020 yılında Çin üzerine yapılan bir çalışmada, gıda rezervi ölçeğindeki değişiklik ve COVID-19'daki taze gıda rezervleri için ödeme yapma istekliliği dahil olmak üzere tüketici gıda stoklama davranışı analiz edilmiştir. Çalışmada, gıda stoklama davranışının bir dizi çoklu motivasyon ve öznel risk algısı tarafindan beslendiği tespit edilmiştir. Elde edilen sonuçlara göre; kadın, yüksek eğitim seviyesi ve yüksek gelirli tüketicilerin daha büyük ölçekli gıda rezervleri ayırma olasılığı daha yüksek olarak tespit edilirken, tüketicilerin taze gıda rezervleri için ödeme yapma istekliliği gelir seviyesine göre değişmektedir (Wang vd., 2020).

Türkiye'de yapılan çalışmalardan bazıları ise şöyledir. ÇAKIROĞLU, Pirtini, ve Çengel (2020) Covid-19 döneminde tüketicilerin yaşam tarzı açısından, tüketici davranışlarındaki farklıklar üzerine yaptıkları çalışmalarında, tüketicilerin temel ihtiyaçlara yöneldiklerini, çevrimiçi alışverişlerinin arttı̆̆ını, dijital platformları daha fazla kullandıklarını tespit etmişlerdir.

KESKIN (2020), Covid-19 pandemi süreciyle beraber gelen kısitlama ve endişelerin tüketicilerin dijital etkileşimini arttırdı̆̆ını, online ticaret verilerinde de önemli değişimlerin yaşandığını tespit etmiştir.

Literatürdeki çalışmalar genel olarak incelendiğinde, tüketicilerin Covid-19 döneminde sadece sağlık ve yaşam tarzlarında değil, aynı zamanda tüketimlerinde de önemli değişimlerin olduğu tespit edilmiştir. Bu çalışmada da Covid-19'un tüketicilerin satın alma davranısları üzerindeki etkisi cinsiyet faktörüne göre incelenmiştir.

\section{Model ve Yöntem}

Bilindiği üzere tüketicinin satın alma sürecini etkileyen birçok faktör vardır. Tüketici kararlarını etkileyen cinsiyet, psikoloji, sosyoloji, çevre vb. faktörlerin yanı sıra Covid19 pandemisi gibi salgınlar da tüketici tercihlerini önemli derecede etkilemektedir. Bun- dan dolayı bu çalışmada, salgın durumlarında bireyin satın alma davranıslarındaki farklllıkların neler olduğunun ve cinsiyet faktörüne göre farklılaşıp farklılaşmadığının, bu çalışmada yapılan anket çalışmasıyla ve literatürde yer alan çalışmalardan elde edilen bilgiler ışı̆̆ında tespit edilmesi amaçlanmıştır. Çalışmanın araştırma yöntemi olarak anket tercih edilmiştir. Araştırmanın ana kütlesini Türkiye'de yaşayan tüketiciler oluşturmakta ve örneklemi 397 kişiden oluşmaktadir. Anket formu 8 demografik soru ve 5'li likert ölçeğinde hazırlanmış 34 sorudan oluşmaktadır. Anket formuna ait 15 ifade KOÇ ve AYDIN (2018) tüketici satın alma davranışlarına yönelik çalışmalarından yararlanılarak Covid-19 dönemine uyarlanmıştır. Hazırlanmış anket formu, Türkiye'de yaşayan 397 katılımcıdan 2020 yılının Eylül ayında basit rastgele örnekleme yöntemi ile online olarak toplanmıştır. Çalı̧̧mada elde edilen veriler SPSS 18 istatistik paket programıla test edilmiştir.

Bulunan araştırma sonuçlarını Covid-19 sürecinde tüm tüketiciler için genellemek sağlıklı olmamakla beraber, sonuçlar genel tüketici profili hakkında bir fikir vermektedir. Dolayısıyla bu çalışma salgın durumlarında tüketicilerin davranışlarındaki değişimleri göz önünde bulundurarak üretim ve satış stratejisi yapan işletmecilere yardımcı olmak ve ayrıca bu alana katkı sağlamak amacıyla uygulanmış bir çalışmadır.

\section{Bulgular ve Genel Değerlendirme}

\subsubsection{Demografik Özellikler}

Çalı̧̧mada bireylerin tüketim davranışlarını belirlemede, cinsiyetin rolü incelenmektedir. Ankete katılanların \% 63,0 (250) oranındaki kısmı kadınlardan, \%37,0 (147) oranındaki kısmı ise erkeklerden oluşmaktadır. Buna göre çalışmada en çok kadın katılımcılar yer almıştır. Diğer demografik özelliklerden de kısaca bahsedecek olursak; katılımclların çoğunluğunun bekâr, 26-35 yaş arası, lisans mezunu, 6501 TL ve üstü gelire sahip, Doğu Anadolu Bölgesi'nde ikamet eden kişi- 
lerden oluştuğu tespit edilmiştir.

\subsection{2 İfadelere İlişkin Bulgular}

Araştırmanın bu bölümünde katılımcıların Covid-19 sürecinde ve öncesine ait haftalık satın alma miktarında meydana gelen değişimleri gösteren bilgiler tablo 1 ve 2 'de belirtilmiştir.

Tablo 1 incelendiğinde Covid-19 döneminden önce haftada en az 1-2 defa alışveriş yapan kişi sayısı 192'dir. 3-4 defa alışveriş yapan kişi sayısı 135, 5-6 defa yapan kişi sayısı 41, 7-8 defa yapan kişi sayısı 12 ve son olarak 9 ve üstü yapan kişi sayısı 11 bulunmuştur. Salgın döneminden önce katılımcıların haftada 1-2 ve 3-4 defa alışveriş yapma alışkanlı̆̆ının daha çok olduğu tespit edilmiştir.

Tablo 1: "Covid-19 Sürecinden Önce Bir Haftada Toplam Kaç Defa Alışveriş (Gıda, Kıyafet, vb.) Yaptığınızı Belirtiniz" İfadesine Ait Frekans Dağılımları

\begin{tabular}{ccccc}
\hline $\begin{array}{c}\text { Haftalık Satın } \\
\text { Alma Miktarı }\end{array}$ & $\begin{array}{c}\text { Frekans } \\
\text { Dağılımları }\end{array}$ & Yüzde & $\begin{array}{c}\text { Geçerli } \\
\text { Yüzde }\end{array}$ & $\begin{array}{c}\text { Kümülatif } \\
\text { Yüzde }\end{array}$ \\
\hline $1-2$ & 192 & 48,4 & 48,4 & 48,4 \\
$3-4$ & 135 & 34,0 & 34,0 & 82,4 \\
$5-6$ & 41 & 10,3 & 10,3 & 92,7 \\
$7-8$ & 12 & 3,0 & 3,0 & 95,7 \\
9 ve üstü & 17 & 4,3 & 4,3 & 100,0 \\
\hline Toplam & 397 & 100,0 & 100,0 & \\
\hline
\end{tabular}

Tablo 2'ye göre Covid-19 döneminde katılımcılardan haftada en az 1-2 defa alışveriş yapan kişi sayısı 280, 3-4 defa yapan kişi sayısı 71, 5-6 defa yapan kişi sayısı 28, 7-8 defa yapan 7 ve son olarak da 9 ve üstü alışveriş yapan kişi sayısı 11 bulunmuştur. Salgınla beraber en fazla alışveriş yapma sıklığının haftada 1-2 sefer olduğu görülmüştür. Dolayısıyla tablo 1 ve 2 karşılaştırıldığında, alışveriş yapma sıklığının haftada en fazla 1-2 defa olduğu, ancak Covid-19 dönemiyle beraber 1-2 defa yapma sıklı̆̆ının daha da arttığı gözlemlenmiştir. Dolayısıyla salgınla beraber katılımcıların alışveriş yapma sıklığında önemli bir azalma olduğu söylenebilir.

Çalışmanın devamında ifadelerin ortalamaları, standart sapmaları ve frekans yüzdeleri ölçülmeye çalışılmıştır. Sorulan sorulara verilen cevaplardan kesinlikle katılmıyorum ve katılmıyorum cevapları olumsuz tu-
Tablo 2: "Covid-19 Sürecinde Bir Haftada Toplam Kaç Defa Alışveriş (Gıda, Kıyafet, vb.) Yaptığınızı Belirtiniz" İfadesine Ait Frekans Dağılımları

\begin{tabular}{ccccc}
\hline $\begin{array}{c}\text { Haftalık Satın } \\
\text { Alma Miktarı }\end{array}$ & $\begin{array}{c}\text { Frekans } \\
\text { Dağılımları }\end{array}$ & Yüzde & $\begin{array}{c}\text { Geçerli } \\
\text { Yüzde }\end{array}$ & $\begin{array}{c}\text { Kümülatif } \\
\text { Yüzde }\end{array}$ \\
\hline $1-2$ & 280 & 70,5 & 70,5 & 70,5 \\
$3-4$ & 71 & 17,9 & 17,9 & 88,4 \\
$5-6$ & 28 & 7,1 & 7,1 & 95,5 \\
$7-8$ & 7 & 1,8 & 1,8 & 97,2 \\
9 ve üstü & 11 & 2,8 & 2,8 & 100,0 \\
\hline Toplam & 397 & 100,0 & 100,0 & \\
\hline
\end{tabular}

tum olarak, kararsızım cevabı kararsız tutum olarak ve kesinlikle katılıyorum ve katılıyorum ise olumlu tutum olarak tablo ??'te belirtilmiştir.

Tablo ??'e göre, Covid-19 döneminde katılımcıların satın alma tutumlarının ortalama değeri 4,40 ile 1,74 arasında değişmektedir. "Covid-19 sürecinde eskisinden daha fazla lokanta ve kafelere gitmeye başladım" ifadesi en yüksek ortalama değere $(4,40)$ sahiptir. "Covid-19 sürecinde açık hava mekânlarını daha fazla tercih ediyorum" ifadesi ise en düşük ortalama değere $(1,74)$ sahiptir.

Standart sapmalar incelendiğinde, en yüksek standart sapma değeri 1,34 ile "Covid-19 sürecinde alışverişlerimde bazen kontrolümü kaybederim, ihtiyacım dışında ürün aldığım olur" ifadesine aittir. En düşük standart sapma değeri ise 0,89 ile "Covid19 sürecinde eskisinden daha fazla lokanta ve kafelere gitmeye başladım" ve "Covid-19 sürecinde ölüm ve vaka sayısı artıkça daha fazla ürün stokluyorum" ifadelerine aittir.

4.0.3 Covid-19 Döneminde Cinsiyetin Satın Alma Davranışı Üzerindeki Etkisi

Tablo ??'te tüketicilerin Covid-19 döneminde cinsiyet faktörüne göre ifadelere katılım dereceleri t-testi ile ölçülmeye çalışılmiştır. T-testi sonucunda elde edilen bilgiler tablo 4'te görüldüğü gibi 32 ifadenin 16'sinda istatistiksel olarak anlamlı bir farklılık bulunmuştur. Bu ifadeler şunlardır;

1.Covid-19 sürecinde ihtiyacımdan fazla alışveriş yapıyorum* ifadesinin $\mathrm{p}$ değeri $0,027<0.05$ bulunduğundan cinsiyet faktörüne göre istatistiksel olarak anlamlı bir fark- 
Tablo 3: Araştırmaya Katılan Katılımcıların Covid-19 Döneminde Satın Alma Alışkanlıklarına İlişkin Frekans Dağılımları

\begin{tabular}{|c|c|c|c|c|c|}
\hline Değişkenler & Ort. & $\begin{array}{l}\text { Standart } \\
\text { Sapma }\end{array}$ & $\begin{array}{l}\text { Olumlu } \\
\text { Tutum } \\
\quad \%)\end{array}$ & $\begin{array}{c}\text { Kararsiz } \\
(\%)\end{array}$ & $\begin{array}{l}\text { Olumsuz } \\
\text { Tutum } \\
(\%)\end{array}$ \\
\hline $\begin{array}{l}\text { 1.Covid-19 sürecinde ihtiyacımdan fazla alışveriş } \\
\text { yapıyorum. }\end{array}$ & 2,55 & 1,22 & 19,4 & 17,6 & 63,0 \\
\hline $\begin{array}{l}\text { 2.Covid-19 sürecinde meyve sebze gibi sağlıklı ürünleri } \\
\text { daha çok satın alıyorum. }\end{array}$ & 2,31 & 1,09 & 58,9 & 25,0 & 16,1 \\
\hline $\begin{array}{l}\text { 3.Covid-19 sürecinde besin takviyesi (vitamin, mineraller, } \\
\text { vb.) satın alımım arttı. }\end{array}$ & 3,04 & 1,33 & 35,8 & 20,4 & 43,8 \\
\hline $\begin{array}{l}\text { 4.Covid-19 sürecinde satın aldığım yiyeceklerin, sağlıklı } \\
\text { yiyecekler olmalarına daha fazla dikkat ediyorum. }\end{array}$ & 2,19 & 1,12 & 63,5 & 22,4 & 14,1 \\
\hline $\begin{array}{l}\text { 5.Covid-19 sürecinde işlenmiş ürün satın alımım artı } \\
\text { (endüstriyel pişmiş ürünler, hazır yemekler). }\end{array}$ & 3,97 & 0,98 & 8,6 & 14,1 & 77,3 \\
\hline $\begin{array}{l}\text { 6.Covid-19 sürecinde en çok gıda alışverişi sırasında } \\
\text { ihtiyacımdan fazla alışveriş yapıyorum. }\end{array}$ & 3,24 & 1,29 & 31,1 & 18,6 & 49,6 \\
\hline $\begin{array}{l}\text { 7.Covid-19 sürecinde en çok giyim alışverişi sırasında } \\
\text { ihtiyacımdan fazla alışveriş yapıyorum. }\end{array}$ & 4,14 & 1,00 & 8,6 & 8,6 & 82,8 \\
\hline $\begin{array}{l}\text { 8.Covid-19 sürecinde en çok elektronik eşya alışverişi } \\
\text { sırasında ihtiyacımdan fazla alışveriş yapıyorum. }\end{array}$ & 4,20 & 0,95 & 7,1 & 6,5 & 86,4 \\
\hline $\begin{array}{l}\text { 9.Covid-19 sürecinde en çok temizlik ürünleri alışverişi } \\
\text { sırasında ihtiyacımdan fazla alışveriş yapıyorum. }\end{array}$ & 2,65 & 1,27 & 46,6 & 23,9 & 29,5 \\
\hline $\begin{array}{l}\text { 10.Covid-19 sürecinde alışverişlerimde bazen kontrolümü } \\
\text { kaybederim, ihtiyacım dışında ürün aldığım olur. }\end{array}$ & 3,63 & 1,17 & 17,9 & 18,4 & 63,7 \\
\hline $\begin{array}{l}\text { 11.Covid-19 sürecinde, öncesine göre eğlence amaçlı } \\
\text { alışverişlerim arttı (Netflix aboneliği, Blu Tv, Puhutv, } \\
\text { Online oyun, vb.). }\end{array}$ & 3,48 & 1,34 & 27,7 & 13,6 & 58,7 \\
\hline $\begin{array}{l}\text { 12. Covid-19 sürecinde satın alacağım ürünün fiyatı her } \\
\text { zaman önemli değildir. }\end{array}$ & 3,73 & 1,09 & 13,4 & 22,1 & 64,5 \\
\hline $\begin{array}{l}\text { 13.Covid-19 sürecinde kampanya ve promosyonlar satın } \\
\text { alma kararımı etkiliyor. }\end{array}$ & 2,91 & 1,16 & 36,1 & 32,2 & 31,8 \\
\hline $\begin{array}{l}\text { 14.Covid-19 sürecinde alısverişlerimde mağaza veya } \\
\text { marketin temiz ve Covid-19 kurallarına uygun olması } \\
\text { satın alma kararımı etkiliyor. }\end{array}$ & 2,02 & 1,02 & 75,1 & 15,6 & 9,3 \\
\hline $\begin{array}{l}\text { 15.Covid-19 sürecinde taksitle satın alma imkânı kararımı } \\
\text { etkiler. }\end{array}$ & 3,20 & 1,27 & 31,7 & 22,2 & 46,1 \\
\hline $\begin{array}{l}\text { 16.Covid-19 sürecinde temassız ödemeyi daha çok tercih } \\
\text { ediyorum. }\end{array}$ & 2,02 & 1,17 & 74,6 & 12,3 & 13,1 \\
\hline $\begin{array}{l}\text { 17.Covid-19 sürecinde daha önce sürekli kullandığım } \\
\text { marka ve ürün dışında başka marka ve ürün tercih } \\
\text { etmiyorum. }\end{array}$ & 3,00 & 1,07 & 30,7 & 33,8 & 35,5 \\
\hline $\begin{array}{l}\text { 18.Daha önce alışveriş yaptığım markaların online } \\
\text { sitelerini Covid-19 sürecinde daha fazla kullanıyorum. }\end{array}$ & 2,67 & 1,18 & 49,4 & 23,9 & 26,7 \\
\hline $\begin{array}{l}\text { 19.Covid-19 sürecinde bir ürünü satın almadan önce o } \\
\text { ürün/hizmet ile ilgili sosyal medyada araştırma } \\
\text { yapıyorum. }\end{array}$ & 2,43 & 1,11 & 53,9 & 29,7 & 16,4 \\
\hline $\begin{array}{l}20 . \text { Covid-19 sürecinde satın alacağım mal ve hizmetlerde } \\
\text { benim için en önemli olan ekonomik durumuma uygun } \\
\text { olmasıdır. }\end{array}$ & 2,11 & 0,97 & 66,0 & 27,2 & 7,8 \\
\hline
\end{tabular}

lılık bulunmuştur. Kadınların ortalaması erkeklerinkinden büyük bulunmuş ve bu da kadınların bu ifadeye erkeklerden daha fazla katılarak, Covid-19 döneminde ihtiyaç fazlası alışveriş yaptı̆̆ını göstermiştir.

5.Covid-19 sürecinde işlenmiş ürün satın alımım artı (endüstriyel pişmiş ürünler, hazır

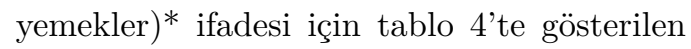


Tablo 3: Devam: Araştırmaya Katılan Katılımcıların Covid-19 Döneminde Satın Alma Alışkanlıklarına İlişkin Frekans Dağı̆lımları

\begin{tabular}{|c|c|c|c|c|c|}
\hline Değişkenler & Ort. & $\begin{array}{l}\text { Standart } \\
\text { Sapma }\end{array}$ & $\begin{array}{l}\text { Olumlu } \\
\text { Tutum } \\
\quad \%)\end{array}$ & $\begin{array}{c}\text { Kararsiz } \\
(\%)\end{array}$ & $\begin{array}{l}\text { Olumsuz } \\
\text { Tutum } \\
(\%)\end{array}$ \\
\hline $\begin{array}{l}\text { 21.Covid-19 sürecinde reklamlar satın alma kararımı } \\
\text { etkiliyor. }\end{array}$ & 3,35 & 1,07 & 18,1 & 40,1 & 41,8 \\
\hline 22.Covid-19 sürecinde sağlıklı yiyecek ve içecekler & 2,58 & 1,01 & 47,1 & 37,0 & 15,9 \\
\hline $\begin{array}{l}\text { konusunda çevrenin görüs ve tavsiyelerini dikkate alırım. } \\
\text { 23.Covid-19 sürecinde eskisinden daha fazla lokanta ve } \\
\text { kafelere gitmeye başladım. }\end{array}$ & 4,40 & 0,89 & 5,1 & 5,7 & 89,2 \\
\hline $\begin{array}{l}\text { 24.Covid-19 sürecinde eskisinden daha fazla dışarıdan } \\
\text { yemek sipariş ediyorum. }\end{array}$ & 4,22 & 0,99 & 7,0 & 10,3 & 82,6 \\
\hline $\begin{array}{l}\text { 25.Covid-19 sürecinde eskisinden daha fazla evde yemek } \\
\text { yapiyorum. }\end{array}$ & 1,93 & 1,10 & 85,0 & 14,6 & 10,3 \\
\hline $\begin{array}{l}\text { 26.Covid-19 sürecinde daha önce hiç yapmadığım } \\
\text { yiyecekleri (yemek, tatlı, ekmek) evde yapmaya başladım. }\end{array}$ & 2,30 & 1,18 & 59,7 & 22,7 & 17,6 \\
\hline $\begin{array}{l}\text { 27.Covid-19 sürecinde sokağa çıkma yasağının olduğu } \\
\text { dönemlerde, gereğinden çok daha fazla alışveriş } \\
\text { yapıyorum. }\end{array}$ & 3,22 & 1,22 & 28,6 & 24,8 & 46,6 \\
\hline $\begin{array}{l}\text { 28. Covid-19 sürecinde internet üzerinden alı̧̧veriş yapmayı } \\
\text { daha fazla tercih ediyorum. }\end{array}$ & 2,36 & 1,17 & 59,7 & 22,2 & 49,4 \\
\hline $\begin{array}{l}\text { 29. Covid-19 çıktıktan sonra hayata karamsar bakıyorum } \\
\text { ve bu yüzden alışveriş yapmak istemiyorum. }\end{array}$ & 3,47 & 1,14 & 17,7 & 22,9 & 49,4 \\
\hline $\begin{array}{l}\text { 30. Covid-19 sürecinde ölüm ve vaka sayısı artıkça daha } \\
\text { fazla ürün stokluyorum. }\end{array}$ & 3,99 & 0,89 & 6,8 & 15,1 & 78,1 \\
\hline $\begin{array}{l}\text { 31. Covid-19 sürecinde açık hava mekanlarını daha fazla } \\
\text { tercih ediyorum. }\end{array}$ & 1,74 & 0,90 & 84,1 & 11,4 & 4,5 \\
\hline $\begin{array}{l}\text { 32.Türkiye ekonomisi ile ilgili beklentilerim olumlu } \\
\text { yöndedir. }\end{array}$ & 3,83 & 1,24 & 15,3 & 21,0 & 63,7 \\
\hline
\end{tabular}

Not:Olumlu tutum; Katılıyorum, Kesinlikle Katıllyorum. Kararsız tutum;Kararsız.

Olumsuz tutum; Katılmıyorum, Kesinlikle Katılmıorum.

p değeri $0,000<0.05$ bulunduğundan, cinsiyet faktörüne göre istatistiksel olarak anlamlı bir farklılık bulunmuştur. Kadınların ortalaması $(4,12)$ erkeklerin ortalamasından $(3,72)$ büyük olduğundan kadınlar erkeklere oranla bu ifadeye daha fazla katılmaktadır. Tablo 3'e göre ise, katılımcıların genel olarak olumsuz cevap verdikleri gözlemlenmiştir. Dolayısıyla erkeklerin büyük çoğunluğunun işlenmiş ürünlere talebinin azaldığı söylenebilir.

6.Covid-19 sürecinde en çok gıda alışverişi sırasında ihtiyacımdan fazla alışveriş yapiyorum* ifadesi Tablo 4'te gösterilen $\mathrm{p}$ değeri $0,040<0.05$ bulunduğundan, cinsiyet faktörüne göre istatistiksel olarak anlamlı bir farklılık bulunmuştur. Kadınların ortalaması $(3,34)$ erkeklerin ortalamasindan $(3,06)$ büyük olduğundan kadınlar erkeklere oranla bu ifadeye daha fazla katılmaktadır. Dolayısıyla kadınların erkeklere oranla daha fazla gida alışverişi yaptığı gözlemlenmiştir.

7.Covid-19 sürecinde en çok giyim alışverişi sırasında ihtiyacımdan fazla alışveriş yapıyorum* ifadesi için tablo 4'te gösterilen $\mathrm{p}$ değeri $0,000<0.05$ bulunduğundan, cinsiyet faktörüne göre istatistiksel olarak anlamlı bir farklılık bulunmuştur. Kadınların ortalaması $(4,28)$ erkeklerin ortalamasindan $(3,91)$ büyük olduğundan kadınlar erkeklere oranla bu ifadeye daha fazla katılmaktadır. Tablo 3'e göre ise, katılımcılarm genel olarak olumsuz cevap verdikleri gözlemlenmiştir. Dolayısıyla Covid-19 döneminde kadınların erkeklerden daha fazla giyim alışverişi yaptığ $\breve{1}_{1}$ söylenebilir.

8.Covid-19 sürecinde en çok elektronik eşya alışverişi sırasında ihtiyacımdan fazla alışveriş yapıyorum.* ifadesi için tablo 4'te 
gösterilen $\mathrm{p}$ değeri $0,000<0.05$ bulunduğundan, cinsiyet faktörüne göre istatistiksel olarak anlamlı bir farklılık bulunmuştur. Kadınların ortalaması $(4,36)$ erkeklerin ortalamasından $(3,93)$ büyük olduğundan kadınlar erkeklere oranla bu ifadeye daha fazla katılmaktadır. Tablo 3'e göre ise, katılımcıların genel olarak olumsuz cevap verdikleri gözlemlenmiştir. Dolayısıyla Covid-19 döneminde erkeklerin neredeyse hiç elektronik alışverişi yapmadığı söylenebilir.

11.Covid-19 sürecinde, öncesine göre eğlence amaçlı alışverişlerim arttı (Netflix aboneliği, Blu Tv, Puhutv, Online oyun, vb.).* ifadesi için tablo 4'te gösterilen $\mathrm{p}$ değeri $0,001<0.05$ bulunduğundan, cinsiyet faktörüne göre istatistiksel olarak anlamlı bir farklılık bulunmuştur. Kadınların ortalaması $(3,36)$ erkeklerin ortalamasindan $(3,19)$ büyük olduğundan kadınlar erkeklere oranla bu ifadeye daha fazla katılmaktadır. Dolayısyyla Covid-19 döneminde kadınların eğlence amaçlı alışverişleri erkeklerden fazladır.

12.Covid-19 sürecinde satın alacağım ürünün fiyatı her zaman önemli değildir.* ifadesi için tablo 4 'te gösterilen p değeri $0,000<0.05$ bulunduğundan, cinsiyet faktörüne göre istatistiksel olarak anlamlı bir farklllık bulunmuştur. Kadınların ortalaması $(3,89)$ erkeklerin ortalamasından $(3,46)$ büyük oldugundan kadınlar erkeklere oranla bu ifadeye daha fazla katılmaktadır. Tablo 3'e göre ise, katılımciların genel olarak olumsuz cevap verdikleri gözlemlenmiştir. Dolayısıyla Covid-19 döneminde erkeklerin kadınlara oranla aldıkları ürünlerin fiyatlarına daha çok önem verdiği görülmüştür.

23.Covid-19 sürecinde eskisinden daha fazla lokanta ve kafelere gitmeye başladım.* ifadesi için tablo 4 'te gösterilen $\mathrm{p}$ değeri $0,000<0.05$ bulunduğundan, cinsiyet faktörüne göre istatistiksel olarak anlaml bir farklılık bulunmuştur. Kadınların ortalaması $(4,48)$ erkeklerin ortalamasindan $(4,10)$ büyük olduğundan kadınlar erkeklere oranla bu ifadeye daha fazla katılmaktadır. Ayrıca tablo 3'e göre de katılımcılarm \% 89,2'si olumsuz cevap vermişlerdir. Dolayısıyla ka- dın ve erkeklerin cafe tercihlerinin çok azaldığ hatta erkeklerin eskiye nazaran neredeyse hiç tercih etmediği söylenebilir.

24.Covid-sürecinde eskisinden daha fazla dışarıdan yemek sipariş ediyorum.* ifadesi için tablo 4 'te gösterilen p değeri $0,000<0.05$ bulunduğundan, cinsiyet faktörüne göre istatistiksel olarak anlamlı bir farklılık bulunmuştur. Kadınların ortalaması $(4,48)$ erkeklerin ortalamasindan $(3,78)$ büyük oldugundan kadınlar erkeklere oranla bu ifadeye daha fazla katılmaktadır. Ayrıca tablo 3'e göre de katılımcıların \%82,6'sı olumsuz cevap vermişlerdir. Dolayısıyla kadın ve erkeklerin dışarıdan yemek siparişlerinin azaldığı ve en fazla erkeklerin dışarıdan yemek sipariş tercihlerinin azaldığı söylenebilir.

25.Covid-19 sürecinde eskisinden daha fazla evde yemek yapiyorum.* ifadesi için tablo 4 'te gösterilen p değeri $0,001<0.05$ bulunduğundan, cinsiyet faktörüne göre istatistiksel olarak anlamlı bir farklılık bulunmuştur. Erkeklerin ortalaması $(2,17)$ kadınların ortalamasından $(1,80)$ büyük olduğundan, erkekler bu ifadeye daha fazla katılmaktadır. Tablo 3'e göre, katılımcıların \%85'i bu ifadeye katılmaktadır. Dolayısıyla erkeklerin bu ifadeye katılımlarının daha fazla olduğu söylenebilir.

26.Covid-19 sürecinde daha önce hiç yapmadığım yiyecekleri (yemek, tatlı, ekmek) evde yapmaya başladım* ifadesi için tablo 4 'te gösterilen $\mathrm{p}$ değeri $0,000<0.05$ bulunduğundan, cinsiyet faktörüne göre istatistiksel olarak anlamlı bir farklılık bulunmuştur. Erkeklerin ortalaması $(2,59)$ kadınlarm ortalamasından $(2,13)$ büyük olduğundan, erkekler bu ifadeye daha fazla katılmaktadır. Dolayısiyla 24 ve 25. ifadeye paralel olarak; erkeklerin dışarıdan yemek siparişinin önemli derece azaldığ 1 ve evde daha fazla yemek yaptığı üstelik yeni lezzetler de denediği gözlemlenmiştir.

27.Covid-19 sürecinde sokağa çıkma yasağının olduğu dönemlerde, gereğinden çok daha fazla alışveriş yapıyorum* ifadesi için tablo 4'te gösterilen p değeri $0,020<0.05$ bulunduğundan, cinsiyet faktörüne göre istatis- 
tiksel olarak anlamlı bir farklılık bulunmustur. Kadınların ortalaması $(3,33)$ erkeklerin ortalamasından $(3,04)$ büyük olduğundan kadınlar erkeklere oranla bu ifadeye daha fazla katılmakta ve daha fazla alışveriş yapmaktadır.

28.Covid-19 sürecinde internet üzerinden alısveriş yapmayı daha fazla tercih ediyorum* ifadesi için tablo 4'te gösterilen $\mathrm{p}$ değeri $0,001<0.05$ bulunduğundan, cinsiyet faktörüne göre istatistiksel olarak anlamlı bir farklılık bulunmuştur. Erkeklerin ortalaması $(2,61)$ kadınların ortalamasından $(2,21)$ büyük olduğundan, erkekler bu ifadeye daha fazla katılmaktadır. Dolayısıyla erkeklerin covid-19 döneminde online tüketiminin arttığı söylenebilir.

30.Covid-19 sürecinde ölüm ve vaka sayısı artıkça daha fazla ürün stokluyorum.* ifadesi için tablo 4 'te gösterilen p değeri $0,000<0.05$ bulunduğundan, cinsiyet faktörüne göre istatistiksel olarak anlaml bir farklıllk bulunmuştur. Kadınların ortalaması $(4,17)$ erkeklerin ortalamasindan $(3,69)$ büyük oldugundan kadınlar erkeklere oranla bu ifadeye daha fazla katılmaktadır. Kadınların Covid19 döneminde ölüm ve vaka sayısındaki artışla beraber daha fazla ürün stokladığı söylenebilir. 31.Covid-19 sürecinde açık hava mekânlarını daha fazla tercih ediyorum.* ifadesi için tablo 4 'te gösterilen p değeri $0,003<0.05$ bulunduğundan, cinsiyet faktörüne göre istatistiksel olarak anlamlı bir farklılık bulunmuştur. Erkeklerin ortalaması $(1,92)$ kadınların ortalamasından $(1,64)$ büyük olduğundan, erkekler bu ifadeye daha fazla katılmaktadır. Dolayısıyla erkekler Covid-19 döneminde açık hava mekânlarını daha fazla tercih etmektedirler.

32.Türkiye ekonomisi ile ilgili beklentilerim olumlu yöndedir.* ifadesi için tablo 4'te gösterilen $\mathrm{p}$ değeri $0,021<0.05$ bulunduğundan, cinsiyet faktörüne göre istatistiksel olarak anlamlı bir farklılık bulunmuştur. Kadınların ortalaması $(3,94)$ erkeklerin ortalamasından $(3,63)$ büyük olduğundan kadınlar erkeklere oranla bu ifadeye daha fazla katılmaktadır. Tablo 3'e göre de katılımcıların bü- yük çoğunluğu $(\%$ 63,7) bu ifadeye olumsuz yanıt vermiştir. Dolayısıyla Covid-19 döneminde erkeklerin ekonomik endişeleri kadınlardan fazladır.

Covid-19 döneminde, Tablo 1, 2, 3, ve 4'e göre genel olarak fizyolojik ihtiyaçlar dışındaki harcamalarda önemli bir düşüşün gerçekleştiği ve özellikle erkek tüketicilerin satın alma davranışlarında önemli bir azalma olduğu söylenebilir.

4.0.4 Demografik Özeliklere Göre Satın Alma Davranışına İlişkin Grup Ortalamalarının Karşılaştırılması

Çalışmanın bu bölümünde tüm likert soruların ortalamaları diğer demografik verilerle test edilmiştir. İki kategorili olanlara t-testi; ikiden fazla kategorili olanlara ise Anova testi yapılmıştır. Yapılan testler sonucunda Covid-19 döneminde cinsiyet faktörü dışında diğer demografik özeliklerden olan eğitim durumu, yaş, medeni durum, gelir düzeyi, sahip olunan çocuk sayısı ve yaşanılan bölgeye göre anlamlı bir farklılık bulunmamıştır. Bu yüzden sonuç olarak Covid-19 döneminde tüketicilerin satın alma davranışlarının benzerlik gösterdiği söylenebilir. 
Tablo 4: İfadelere İlişkin T-testi

\begin{tabular}{|c|c|c|c|c|c|c|c|}
\hline \multirow[b]{2}{*}{ Değişkenler } & \multirow[b]{2}{*}{ Gruplar } & \multirow[b]{2}{*}{$\mathrm{N}$} & \multirow[b]{2}{*}{ Ort. } & \multirow[b]{2}{*}{ Ss } & \multicolumn{3}{|c|}{ t-testi } \\
\hline & & & & & $\mathrm{t}$ & sd & $\mathrm{p}$ \\
\hline \multirow{2}{*}{$\begin{array}{l}\text { 1. Covid-19 sürecinde ihtiyacımdan fazla alışveriş } \\
\text { yapıyorum.* }\end{array}$} & Kadın & 250 & 3,66 & 1,11 & 2,23 & 260,2 & ,027 \\
\hline & Erkek & 147 & 3,36 & 1,36 & & & \\
\hline \multirow{2}{*}{$\begin{array}{l}\text { 2. Covid-19 sürecinde meyve sebze gibi sağlıklı ürünleri } \\
\text { daha çok satın alıyorum. }\end{array}$} & Kadın & 250 & 2,24 & 1,09 & 1,77 & 395 &, 077 \\
\hline & Erkek & 147 & 2,44 & 1,09 & & & \\
\hline \multirow{2}{*}{$\begin{array}{l}\text { 3. Covid-19 sürecinde besin takviyesi (vitamin, mineraller, vb.) } \\
\text { satın alımım arttı. }\end{array}$} & Kadın & 250 & 3,07 & 1,36 &, 65 & 395 &, 520 \\
\hline & Erkek & 147 & 2,98 & 1,28 & & & \\
\hline \multirow{2}{*}{$\begin{array}{l}\text { 4. Covid-19 sürecinde satın aldı̆̆ım yiyeceklerin, sağlıklı } \\
\text { yiyecekler olmalarına daha fazla dikkat ediyorum. }\end{array}$} & Kadın & 250 & 2,19 & 1,11 &, 01 & 395 &, 991 \\
\hline & Erkek & 147 & 2,19 & 1,14 & & & \\
\hline \multirow{2}{*}{$\begin{array}{l}\text { 5. Covid-19 sürecinde işlenmiş ürün satın alımım artı } \\
\text { (endüstriyel pişmiş ürünler, hazır yemekler).* }\end{array}$} & Kadın & 250 & 4,12 &, 89 & 3,82 & 262,9 & ,000 \\
\hline & Erkek & 147 & 3,72 & 1,07 & & & \\
\hline \multirow{2}{*}{$\begin{array}{l}\text { 6. Covid-19 sürecinde en çok gıda alışverişi sırasında } \\
\text { ihtiyacımdan fazla alışveriş yapıyorum.* }\end{array}$} & Kadın & 250 & 3,34 & 1,29 & 2,06 & 395 & , 040 \\
\hline & Erkek & 147 & 3,06 & 1,27 & & & \\
\hline \multirow{2}{*}{$\begin{array}{l}\text { 7. Covid-19 sürecinde en çok giyim alışverişi sırasında } \\
\text { ihtiyacımdan fazla alışveriş yapıyorum.* }\end{array}$} & Kadın & 250 & 4,28 &, 90 & 3,62 & 395 & , 000 \\
\hline & Erkek & 147 & 3,91 & 1,11 & & & \\
\hline \multirow{2}{*}{$\begin{array}{l}\text { 8. Covid-19 sürecinde en çok elektronik eşya alı̧̧verişi } \\
\text { sırasında ihtiyacımdan fazla alışveriş yapıyorum.* }\end{array}$} & Kadın & 250 & 4,36 &, 83 & 4,36 & 395 &, 000 \\
\hline & Erkek & 147 & 3,93 & 3,09 & & & \\
\hline \multirow{2}{*}{$\begin{array}{l}\text { 9. Covid-19 sürecinde en çok temizlik ürünleri alışverişi } \\
\text { sırasında ihtiyacımdan fazla alışveriş yapıyorum. }\end{array}$} & Kadın & 250 & 2,62 & 1,32 & ,66 & 331,2 &, 504 \\
\hline & Erkek & 147 & 2,71 & 1,19 & & & \\
\hline \multirow{2}{*}{$\begin{array}{l}\text { 10. Covid-19 sürecinde alışverişlerimde bazen kontrolümü } \\
\text { kaybederim, ihtiyacım dışında ürün aldığım olur }\end{array}$} & Kadın & 250 & 3,70 & 1,15 & 1,51 & 395 & ,131 \\
\hline & Erkek & 147 & 3,52 & 1,20 & & & \\
\hline \multirow{2}{*}{$\begin{array}{l}\text { 11. Covid-19 sürecinde, öncesine göre eğlence amaçlı alışverişlerim } \\
\text { arttı (Netflix aboneliği, Blu Tv, Puhutv, Online oyun, vb.).* }\end{array}$} & Kadın & 250 & 3,66 & 1,31 & 3,40 & 395 & ,001 \\
\hline & Erkek & 147 & 3,19 & 1,35 & & & \\
\hline \multirow{2}{*}{$\begin{array}{l}\text { 12. Covid-19 sürecinde satın alacă̆ım ürünün fiyatı her zaman } \\
\text { önemli değildir.* }\end{array}$} & Kadın & 250 & 3,89 & 1,06 & 3,77 & 395 & , 000 \\
\hline & Erkek & 147 & 3,46 & 1,09 & & & \\
\hline 13. Covid-19 sürecinde kampanya ve promosyonlar satın alma & Kadın & 250 & 2,90 & 1,16 & ,43 & 395 & ,666 \\
\hline kararımı etkiliyor. & Erkek & 147 & 2,95 & 1,16 & & & \\
\hline 14. Covid-19 sürecinde alışverişlerimde mağaza veya marketintemiz & Kadın & 250 & 2,00 & 1,05 &, 59 & 395 &, 550 \\
\hline ve Covid-19 kurallarına uygun olması satın alma kararımı etkiliyor. & Erkek & 147 & 2,06 &, 99 & & & \\
\hline 15. Covid-19 sürecinde taksitle satın alma imkânı kararımı & Kadın & 250 & 3,28 & 1,28 & 1,76 & 395 & ,078 \\
\hline etkiler. & Erkek & 147 & 3,05 & 1,24 & & & \\
\hline 16. Covid-19 sürecinde temassız ödemeyi daha çok tercih & Kadın & 250 & 2,05 & 1,20 &, 73 & 395 & ,463 \\
\hline ediyorum. & Erkek & 147 & 1,96 & 1,14 & & & \\
\hline 17. Covid-19 sürecinde daha önce sürekli kullandığım marka & Kadın & 250 & 3,02 & 1,09 &, 45 & 395 & 647 \\
\hline ve ürün dışında başka marka ve ürün tercih etmiyorum. & Erkek & 147 & 2,97 & 1,04 & & & \\
\hline 18. Daha önce alışveriş yaptığım markaların online sitelerini & Kadın & 250 & 2,66 & 1,21 &, 38 & 395 & ,702 \\
\hline Covid-19 sürecinde daha fazla kullanıyorum. & Erkek & 147 & 2,70 & 1,14 & & & \\
\hline 19. Covid-19 sürecinde bir ürünü satın almadan önce o ürün/hizmet & Kadın & 250 & 2,35 & 1,09 & 1,96 & 395 & ,051 \\
\hline ile ilgili sosyal medyada araştırma yapıyorum. & Erkek & 147 & 2,57 & 1,14 & & & \\
\hline 20. Covid-19 sürecinde satın alacağım mal ve hizmetlerde benim & Kadın & 250 & 2,11 &, 98 &, 16 & 395 & ,866 \\
\hline için en önemli olan ekonomik durumuma uygun olmasıdır. & Erkek & 147 & 2,12 &, 96 & & & \\
\hline 21. Covid-19 sürecinde reklamlar satın alma kararımı & Kadın & 250 & 3,35 & 1,10 &, 04 & 395 &, 964 \\
\hline 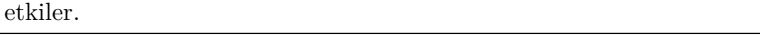 & Erkek & 147 & 3,34 & 1,02 & & & \\
\hline 22. Covid-19 sürecinde sağlıklı yiyecek ve içecekler & Kadın & 250 & 1,04 & 1,04 &, 661 & 395 &, 509 \\
\hline konusunda çevrenin görüş ve tavsiyelerini dikkate alırım. & Erkek & 147 & 2,62 &, 97 & & & \\
\hline 23. Covid-19 sürecinde eskisinden daha fazla lokanta ve & Kadın & 250 & 4,58 & ,69 & 4,81 & 217,1 & , 000 \\
\hline kafelere gitmeye başladım.* & Erkek & 147 & 4,10 & 1,09 & & & \\
\hline 24. Covid-sürecinde eskisinden daha fazla dışarıdan & Kadın & 250 & 4,48 &, 78 & 6,52 & 226,4 & , 000 \\
\hline yemek sipariş ediyorum. ${ }^{*}$ & Erkek & 147 & 3,78 & 1.14 & & & \\
\hline 25. Covid-19 sürecinde eskisinden daha fazla evde yemek & Kadın & 250 & 1,80 & 1,07 & 3,23 & 395 & ,001 \\
\hline yapıorum. ${ }^{*}$ & Erkek & 147 & 2,17 & 1,11 & & & \\
\hline 26. Covid-19 sürecinde daha önce hiç yapmadığım yiyecekleri & Kadın & 250 & 2,13 & 1,15 & 3,79 & 395 & , 000 \\
\hline (yemek, tatlı, ekmek) evde yapmaya başladım.* & Erkek & 147 & 2,59 & 1,18 & & & \\
\hline
\end{tabular}

\footnotetext{
Bir sonraki sayfada devam ediyor ...
} 
Tablo 4: Devam: İfadelere İlişkin T-testi

\begin{tabular}{|c|c|c|c|c|c|c|c|}
\hline \multirow[b]{2}{*}{ Değişkenler } & \multirow[b]{2}{*}{ Gruplar } & \multirow[b]{2}{*}{$\mathrm{N}$} & \multirow[b]{2}{*}{ Ort. } & \multirow[b]{2}{*}{ Ss } & \multicolumn{3}{|c|}{ t-testi } \\
\hline & & & & & $\mathrm{t}$ & $\mathrm{sd}$ & $\mathrm{p}$ \\
\hline \multirow{2}{*}{$\begin{array}{l}\text { 27. Covid-19 sürecinde sokă̆a çıkma yasağının olduğu dönemlerde, } \\
\text { gereğinden çok daha fazla alışveriş yapıyorum.* }\end{array}$} & Kadın & 250 & 3,33 & 1,28 & 2,33 & 344,3 &, 020 \\
\hline & Erkek & 147 & 3,04 & 1,10 & & & \\
\hline \multirow{2}{*}{$\begin{array}{l}\text { 28. Covid-19 sürecinde internet üzerinden alışveriş yapmayı } \\
\text { daha fazla tercih ediyorum.* }\end{array}$} & Kadın & 250 & 2,21 & 1,16 & 3,27 & 395 & ,001 \\
\hline & Erkek & 147 & 2,61 & 1,16 & & & \\
\hline \multirow{2}{*}{$\begin{array}{l}\text { 29.Covid-19 çlktıktan sonra hayata karamsar bakıyorum ve bu } \\
\text { yüzden alışveriş yapmak istemiyorum. }\end{array}$} & Kadın & 250 & 3,50 & 1,19 & , 77 & 395 & ,437 \\
\hline & Erkek & 147 & 3,41 & 1,07 & & & \\
\hline \multirow{2}{*}{$\begin{array}{l}\text { 30.Covid-19 sürecinde ölüm ve vaka sayısı artıkça daha fazla } \\
\text { ürün stokluyorum.* }\end{array}$} & Kadın & 250 & 4,17 & ,81 & 5,17 & 272,7 & ,000 \\
\hline & Erkek & 147 & 3,69 &, 94 & & & \\
\hline \multirow{2}{*}{$\begin{array}{l}\text { 31.Covid-19 sürecinde açık hava mekanlarını daha fazla } \\
\text { tercih ediyorum.* }\end{array}$} & Kadın & 250 & 1,64 & ,84 & 3,03 & 395 &, 003 \\
\hline & Erkek & 147 & 1,92 & ,96 & & & \\
\hline \multirow{2}{*}{$\begin{array}{l}\text { 32. Türkiye ekonomisi ile ilgili beklentilerim olumlu } \\
\text { yöndedir.* }\end{array}$} & Kadın & 250 & 3,94 & 1,18 & 2,31 & 281 & 021 \\
\hline & Erkek & 147 & 3,63 & 1,31 & & & \\
\hline
\end{tabular}

* Yapılan t testi sonucuna göre; 0.05 anlamlllık düzeyinde cinsiyet faktörüne göre anlamlı bir fark bulunan ifadeler.

\section{Sonuç}

Covid-19 salgını birçok bireyin hasta olmasina ve ölmesine sebebiyet vererek tüm dünyayı önemli derecede etkilemiştir. Bu sebeple tüm ülkelerde salgmla mücadele için sosyal mesafe, karantina, sokağa çıkma yasakları gibi farklı uygulamalar yapılmıştır. Bu uygulamalar tüketici davranışlarında önemli değişimlere neden olmuştur. Bu çalışmanın amacı, tüketici davranışlarında ne gibi değişimler olduğunun ve cinsiyet faktörünün de bu davranış değişimlerinde etkisinin olup olmadığının analiz edilmesidir.

Yapılan analizler neticesinde Covid-19 döneminde tüketicilerin genel olarak hayatını devam ettirmek için temel ihtiyaçlara yöneliminin diğer ihtiyaçlara göre önemli derecede arttı̆̆ 1 , sağlıklı tüketime daha fazla önem verdiği, online tüketim ve hijyen ürünlerine taleplerinin $\operatorname{arttığ} 1$ ve daha az cafe ve restoranlara gittiği, gidenlerin de açı hava oturma yerlerini daha fazla tercih ettikleri tespit edilmiştir.

Cinsiyet faktörüne göre yapılan analizler neticesinde ise, kadın ve erkeklerin davranışlarında anlamlı düzeyde bir farklılık gözlemlenmiştir. Bu farklılıklara göre kadınların panik durumunda ihtiyaç fazlası alışveriş yaptığı, satın aldıkları ürünlerin fiyatının önemli olduğu, erkeklerin ise online tüketime daha fazla ilgi gösterdiği ve dışarıdan yemek sipari- şini azaltarak evde yemek yapımına olan talebini artırdığı gözlemlenmiştir. Ayrıca erkeklerin kadınlara göre harcamaları önemli düzeyde azalmıştır. Kadın ve erkeklerin benzer davranışlar sergilediği durumlar da olmuştur. Örneğin salgın döneminde hastalıkla mücadelede sağlıklı beslenme ve hijyen ürünlerine olan talebin hem kadınlar hem de erkekler için önemli derecede arttığı tespit edilmiştir.

Özetle yapılan anket uygulaması sonrasinda katılımcıların cinsiyet faktörüne bağlı olarak Covid-19 döneminde davranışlarının birbirinden farklı olduğu gözlemlenmiştir. Ancak araştırma sonuçlarını Covid-19 sürecinde tüm tüketiciler için genellemek sağlıklı olmamakla beraber, sonuçlar genel tüketici profili hakkında bir fikir vermektedir. Literatüre baktığımızda da bireylerin pandemi döneminde satın alma davranışlarının değiştiği, temel tüketime olan talebin daha fazla olduğu, kadın ve erkeklerin birbirinden farklı davranışlar sergiledikleri gözlemlenmiştir. Bu yüzden işletmelerin, pandemi süreci gibi tüketici davranışlarını etkileyecek durumlarla karşılaşması durumunda, bireylerin ihtiyaçlarını karşılarken cinsiyet faktörünü de göz önünde bulundurması gerekmektedir. 


\section{Kaynakça}

Brizi, A., ve Biraglia, A. (2021, jan). "do i have enough food?" how need for cognitive closure and gender impact stockpiling and food waste during the COVID-19 pandemic: A cross-national study in india and the united states of america. Personality and Individual Differences, 168, 110396. Retrieved from https://doi.org/10.1016\%2Fj.paid. 2020 .110396 doi:10.1016/j.paid.2020.110396

ÇAKIROĞLU, I., Pirtini, S., ve Çengel, Ö. (2020). Covid-19 sürecinde ve post-pandemï döneminde yaşam tarzi açisindan tüketici davranişlarinin değissen eğilimï üzerine kavramsal bïr çalişma. İstanbul Ticaret Üniversitesi Sosyal Bilimler Dergisi, 19(37), 81-103.

Clemens, K. S., Matkovic, J., Faasse, K., ve Geers, A. L. (2020, oct). Determinants of safetyfocused product purchasing in the united states at the beginning of the global COVID-19 pandemic. Safety Science, 130, 104894. Retrieved from https://doi.org/10.1016\% $2 \mathrm{Fj}$.ssci .2020 .104894 doi:10.1016/j.ssci.2020.104894

Hassen, T. B., Bilali, H. E., ve Allahyari, M. S. (2020, aug). Impact of COVID-19 on food behavior and consumption in qatar. Sustainability, 12(17), 6973. Retrieved from https://doi.org/10.3390\% 2Fsu12176973 doi:10.3390/su12176973

KESKİN, S. (2020). Covid-19 salgını sürecinde kısıtlamaların ve endişelerin tüketici davranışına etkileri. Ahi Evran Akademi, 1(2), 69-82.

KOÇ, E., ve AYDIN, F. (2018, jan). CiNSiYETin SATIN ALMA KARARLARI ÜZERINDEKï ETKïsinin DAVRANIşSAL iKTiSAT PERSPEKTïiNDEN DEğERLENDiriLMESi. SOCIAL MENTALITY AND RESEARCHER THINKERS JOURNAL, 4(10), 298-306. Retrieved from https://doi.org/10.31576\%2Fsmryj .60 doi: $10.31576 /$ smryj.60

Vijai, C., ve Nivetha, P. (2020). A study on coronavirus (covid-19) impact of consumer buying behavior with special reference to chennai city. İçinde: International conference on covid-19 studies.

Wang, E., An, N., Gao, Z., Kiprop, E., ve Geng, X. (2020, aug). Consumer food stockpiling behavior and willingness to pay for food reserves in COVID-19. Food Security, 12(4), 739-747. Retrieved from https://doi.org/10.1007\%2Fs12571 -020-01092-1 doi:10.1007/s12571-020-01092-1 


\title{
Investigation Of Consumers' Purchase Behaviors By Gender In The Pandemic Process
}

\author{
EsRa KOÇ (1) ${ }^{1}$ FAtma Fehime AYDIN (iD ${ }^{2}$
}

Received:11.05.2021; Revised:15.06.2021; Accepted:26.06.2021

\begin{abstract}
The COVID-19 pandemic that emerged in late 2019 significantly affected the whole world. Policies used by governments to prevent the COVID-19 pandemic have also affected the behavior of consumers. It is not easy to predict how the pandemic, which emerged as an unusual situation, will affect the purchasing behavior of consumers. In the study, it is aimed to investigate the effect of COVID-19 on the purchasing behavior of consumers depending on the gender factor. For this purpose, the survey method was applied in the study. The sample of the study consists of 397 people. The study was conducted on Turkey. T-test and variance analysis were used in this survey study. According to the findings obtained as a result of the research, it has been determined that the behavior of consumers changed significantly during the COVID-19 period and these changes were especially aimed at meeting the physiological and safety needs, which are one of their basic needs. A significant difference was observed in the behaviors of women and men. It has been observed that women shop more in case of panic, while men are more interested in online consumption. There have also been cases where men and women exhibit similar behavior. For example, it has been found that the demand for healthy nutrition and hygiene products has increased significantly for both women and men during the epidemic period.
\end{abstract}

JEL codes: D12, D91, I18

Keywords: Covid-19 Pandemic, Consumer Behavior, Gender Effect

\section{Extended Summary}

The concept of consumption is defined as the use or utilization of goods or services to meet the needs of individuals (Dinler, 2008). A consumer is defined as a person who decides to purchase marketing components in line with the wishes, desires and needs of himself and his immediate surroundings (Ka-

1 Anadolu University, Eskişehir, Turkey, email: e_k@anadolu.edu.tr

${ }^{2}$ Van Yuzuncu Yil University, Van, Turkey, email: fatmafehimeaydin@yyu.edu.tr rabulut, 1989). All living things consume in the field of food and health in order to maintain their lives, and they also make nonnecessary consumption for wants and desires, apart from consumption to sustain their lives (Durmaz et al., 2020).

Consumer behavior is defined as a process that affects decisions such as choosing, purchasing, using and disposing of products or services that individuals think they can meet their own or others' wishes and needs, and the activities related to these (Kavas et al., 
1995). Purchasing behavior forms the basis of consumer behavior. The purchasing stage is a process of purchasing behavior. Main features of consumer behavior are listed as being a motivated behavior, expressing a dynamic process, dealing with different roles, being affected by environmental factors, showing different behaviors for different consumers, being complex and showing differences in terms of timing (Erdem, 2018). As consumer purchasing behavior can change according to time and conditions it has a flexible structure. Psychological, demographic and socio-cultural factors greatly change consumer purchasing behavior (Yıldız, 2020). Consumption and consumer behavior have an important place in our daily life and in the world of marketing. In order for businesses to have a good place in the market sector, they need to know exactly the factors that affect consumer purchasing behavior. In addition, pandemic processes such as Covid-19 also affect consumer purchasing behavior. Covid-19 is a virus that first appeared in China's Wuhan Province in late December 2019 and was identified on January 13, 2020, as a result of examinations in a group of patients who showed symptoms such as respiratory tract problems, fever, cough, and shortness of breath (http-1). Countries have tried to reduce the risk of transmission by applying various restrictions against this contagious and deadly virus. With these restrictions, radical changes took place in the areas, places and interactions that are the basis of daily life. These radical changes have caused consumers to lose their continuous habits and routines and replace them with new habits (http-2). It is not easy to predict how the pandemic, which has emerged as an extraordinary situation, will affect the purchasing behavior of consumers. According to Jones (2020), consumers' lives will be divided into pre-pandemic and post-pandemic lives, and there will be a significant difference between these two lives. Since the Covid-19 pandemic is a topic that has been on the agenda recently, there are not many studies in the literature on the subject. According to one of these limited studies, it has been observed that the purchasing behavior of consumers has fundamentally changed, consumers are spending more money on health and hygiene products, and brand preference is affected (Vijai and Nivetha, 2020). In another study investigating the immediate effects on consumer awareness, attitudes and behaviors related to food consumption, it was revealed that there are clear changes in the way consumers eat, shop and interact with food (Ben Hassen et al., 2020). In a study on food stocking, it was seen that the COVID-19 epidemic encouraged individuals to stock up on surplus food, individuals did not consume a significant portion of the stocked food, and there was an increasing amount of product wastage (Brizi and Biraglia, 2021). Another study found that female, highly educated, and high-income consumers are more likely to stockpile food on a large scale (Wang et al., 2020). In a study on the differences in consumer behavior in terms of lifestyles of consumers during the Covid-19 period, it was found that consumers tended towards basic needs, increased their online shopping, and used digital platforms more (Çakıroğlu, Pirtini, \& Çengel, 2020). It has been determined that the restrictions and concerns that come with the Covid-19 pandemic process increase the digital interaction of consumers and significant changes are experienced in online trade data (Keskin 2020). In addition, in a study of who buys safety and health care products as a precautionary measure in the early stages of the spread of COVID-19 and what stimulates this action, it has been observed that uncertainty and concern about having a COVID-19 risk factor, not differences in age, gender, race or income, increase the purchase of health and safety products for precautionary purposes (Clemens et al., 2020). When the studies in the literature are examined in general, it has been determined that there are significant changes not only in the health and lifestyles of consumers, but also in their consumption during the Covid- 
19 period. However, since there are not enough studies on how consumer behavior changed in terms of gender factor in this period, it is important for the economics literature to conduct this study.

In this study, it is aimed to determine what the differences in the purchasing behavior of the individual in epidemic situations are and whether they differ according to the gender factor, in the light of the survey study conducted in this study and the information obtained from the studies in the literature. For this purpose, the survey method was used in the study. The main mass of the research consists of consumers living in Turkey and the sample consists of 397 people. The questionnaire form consists of 8 demographic questions and 34 questions prepared on a 5-point Likert scale. The 15 statements of the questionnaire were adapted to the Covid19 period by benefiting from the studies of Koç and Aydın (2018) on consumer purchasing behaviors. The prepared questionnaire was collected online from 397 participants living in Turkey with simple random sampling method in September 2020. The data obtained in the study were tested with the SPSS 18 statistical package program. T-test and analysis of variance were used in the obtained data. Although it is not healthy to generalize the research results for all consumers during the Covid-19 process, the results give an idea about the general consumer profile. Therefore, this study is a study applied in order to help the operators who make production and sales strategies by considering the changes in the behavior of consumers in epidemic situations and also to contribute to this field. According to the findings obtained as a result of the research, it has been determined that the behavior of consumers has changed significantly during the COVID-19 period and that these changes are especially changes to meet the physiological and safety needs, which are among the basic needs. A significant difference was also observed in the behavior of men and women. It has been observed that women shop more than they need in case of panic, while men show more interest in online consumption. There have also been cases where men and women have exhibited similar behavior. For example, it was determined that the demand for healthy nutrition and hygiene products in the fight against the disease increased significantly for both women and men.

In summary, after the survey application, it was observed that the behaviors of the participants were different from each other during the Covid-19 period, depending on the gender factor. When we look at the literature, it has been observed that the purchasing behavior of individuals has changed during the pandemic period, the demand for basic consumption is higher, and men and women exhibit different behaviors. Therefore, if businesses encounter situations that will affect consumer behavior such as the pandemic process, they should also consider the gender factor while meeting the needs of individuals. 